\title{
Religiosidad popular andaluza Testimonio de un patrimonio que nos identifica
}

Esther Fernández de Paz

Departamento de Antropología Social Universidad de Sevilla

\section{Resumen}

Este artículo intenta resaltar el interés que revisten las manifestaciones de la religiosidad popular andaluza como testimonios de un patrimonio que nos identifica, $y$ que es exponente tanto de un modo común de expresión del pueblo andaluz como de los sugerentes matices que aporta nuestra propia pluralidad sociocultural. Unos elementos entendidos desde sus raíces tradicionales, adaptados, y por tanto vivos, en su reproducción cultural actual. Sólo atendiendo a esos modos particulares de vivir la religión puede llegarse al entendimiento global y no objetual de esta parte de nuestro patrimonio cultural.

\section{Palabras clave}

Andalucía / Religiosidad popular / Ermitas / Romerías / Cultura / Identidad / Tradición / Patrimonio Etnológico

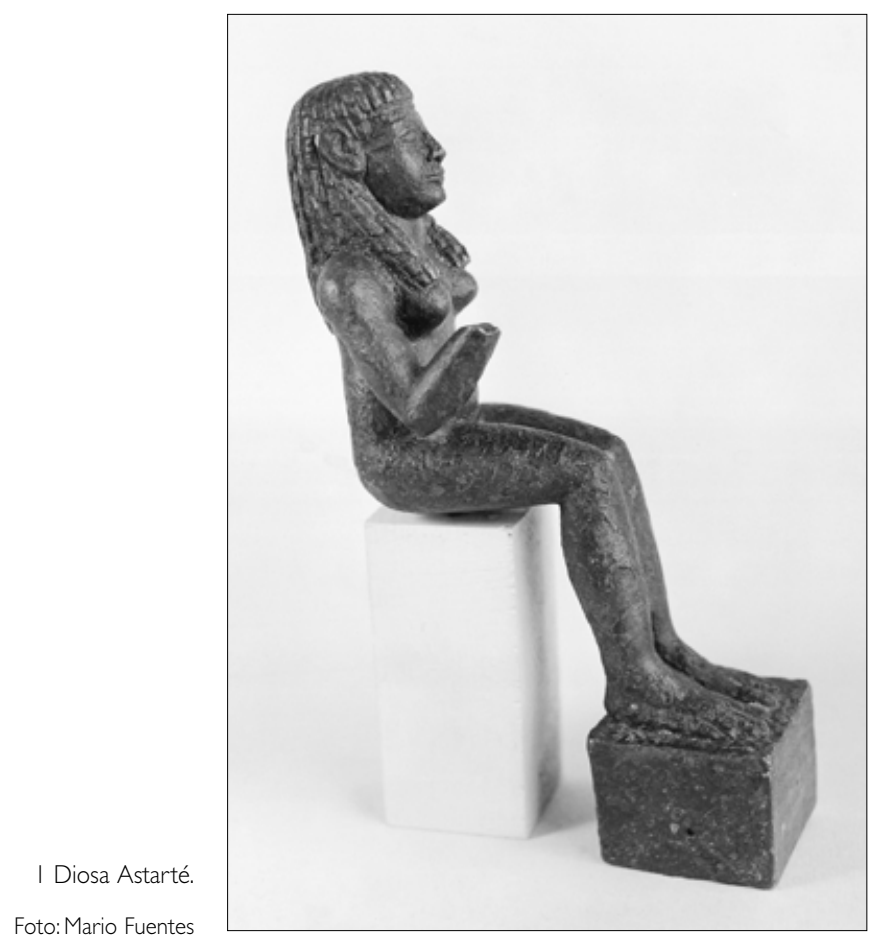

Uno de los factores culturales más complejos del pueblo andaluz son sus expresiones de religiosidad popular. Un concepto -religiosidad popular- que indudablemente no se circunscribe a un sector de la sociedad, ni a las clases iletradas, ni al mundo rural, etc.; no está expresando, por tanto, la extendida oposición culto/popular o rural/urbano, como mundos independientes y contrapuestos, sino ese modo especial que tiene cada sociedad, cada cultura en su conjunto, de añadir sus propias vivencias, su propia experiencia cultural, al núcleo básico de las enseñanzas religiosas. Es, por tanto, la combinación de los planteamientos ortodoxos con tradiciones culturales, que conducen las más de las veces a una separación entre la expresión verbal y la conducta física, entre la aceptación teórica de determinadas ideas y el modo observable en que se llevan a la práctica.

Esta mezcla se presenta más o menos equilibrada, dependiendo de los pueblos y asimismo de las épocas que se analicen, pero es innegable que en la Andalucía actual se da un fuerte desequilibrio a favor de los componentes tradicionales; unos elementos definidores de las manifestaciones de nuestra religiosidad popular, que sin duda constituyen un reflejo de la cultura de la comunidad que les da vida, siendo por tanto sentidas como un símbolo de identificación y de pertenencia al grupo.

Ahí radica su interés patrimonial, pues sólo teniendo esto en cuenta pueden explicarse las formas concretas de nuestra ritualidad, la resonancia afectiva de múltiples devociones incluso en personas no religiosas, la inevitabilidad de acudir a los lugares de origen en determinadas celebraciones, principalmente en las fiestas patronales, o la propia mudanza de éstas a fechas veraniegas para facilitar la participación de los emigrantes como integrantes de un colectivo que los identifica. Igualmente explica el hecho de que los padres inscriban a sus hijos el mismo día del nacimiento en su hermandad patronal o penitencial para continuar la tradición familiar. En definitiva, para transmitir unas pautas culturales, siempre renovadas pero siempre conectadas con el sentir tradicional que las originó y las mantiene.

\section{Raíces que se pierden en el tiempo}

Para ahondar en las claves interpretativas de la religiosidad popular andaluza, es preciso retroceder más allá de la cristianización primitiva de la región, pues cuando se extendieron las doctrinas católicas, ya se hallaban consolidadas en Andalucía algunas de sus más claras inclinaciones, tal como es el caso del culto a 
poderosas imágenes maternas; culto que, por encima de los posteriores y continuos cambios de denominación (Astarté, Tanit, Artemisa, Afrodita, Diana, Venus, Mitra...), siempre se ha mantenido como un rasgo fundamental en la religiosidad popular de los andaluces.

A esta preferencia por las devociones marianas contribuyeron enormemente dos culturas tan distintas como Roma y el Islam, de quienes tomamos los sentimientos de sumisión y fatalismo ante la voluntad divina. Esto puede provocar, en expresión de Domínguez Morano, una fuerte rebeldía, opuesta a la sumisión, que desemboca en una ambivalencia respecto a un Dios "vivido a niveles inconscientes como padre fatal, arbitrario y causante quizá de la desgracia y opresión que este pueblo ha sufrido de modo casi ininterrumpido a lo largo de su historia milenaria", frente al cual, la ya arraigada religiosidad mariana se intensifica al ver en la figura materna la protección y el consuelo necesarios frente al Dios-Padre I.

Ese mismo atributo de mediación entre la autoridad del padre, por lo general ausente de la casa, y los hijos es, sin duda, una de las notas más definitorias de la madre andaluza tradicional. De esta forma, el modo andaluz de sentir las relaciones familiares se traspasa al terreno religioso, haciendo "bastante comprensible la atracción de los andaluces por ese símbolo tan querido e idealizado por ellos en la vida cotidiana"2. De hecho, no puede descartarse que la Iglesia intuyera esta afinidad psicológica con algunos patrones familiares en su esfuerzo por que la cristiandad fuera acrecentando esta devoción, dejando de considerar a María únicamente como Madre de Dios, alejada de los asuntos humanos, y haciéndola entrar en la dinámica de mediación ante la divinidad.

En Andalucía, además, se dio la circunstancia de que a medida que avanzaban las tropas cristianas, la falta de santos en los territorios hasta entonces musulmanes se va supliendo directamente con imágenes de la Virgen, a la vez que coincidió la revitalización del cristianismo en nuestro territorio con una época de máximo despliegue de manifestaciones religiosas populares, que en seguida la Iglesia misma propició en las doctrinas tridentinas.

Así, desde la época barroca el culto a la Virgen es el predominante en Andalucía. Baste recordar cómo la "Tierra de María Santísima" defendió y festejó la proclamación de las bulas de la Inmaculada Concepción en el siglo XVII. Desde entonces la superioridad de esta devoción es indiscutible. Un recorrido por las ermitas y santuarios de nuestro territorio atestigua sobradamente la hegemonía del culto mariano, en correspondencia con las numerosas Vírgenes erigidas como patronas de una localidad. Del mismo modo, en una celebración tan específica como la conmemoración de la Pasión de Jesús, el pueblo andaluz ha ido acrecentando progresivamente el protagonismo de las Vírgenes Dolorosas, hasta el punto de que, en general, parece que el sufrimiento de la madre que ve a su hijo maltratado hasta la muerte, atrae mucho más la atención que el propio dolor de los Cristos.
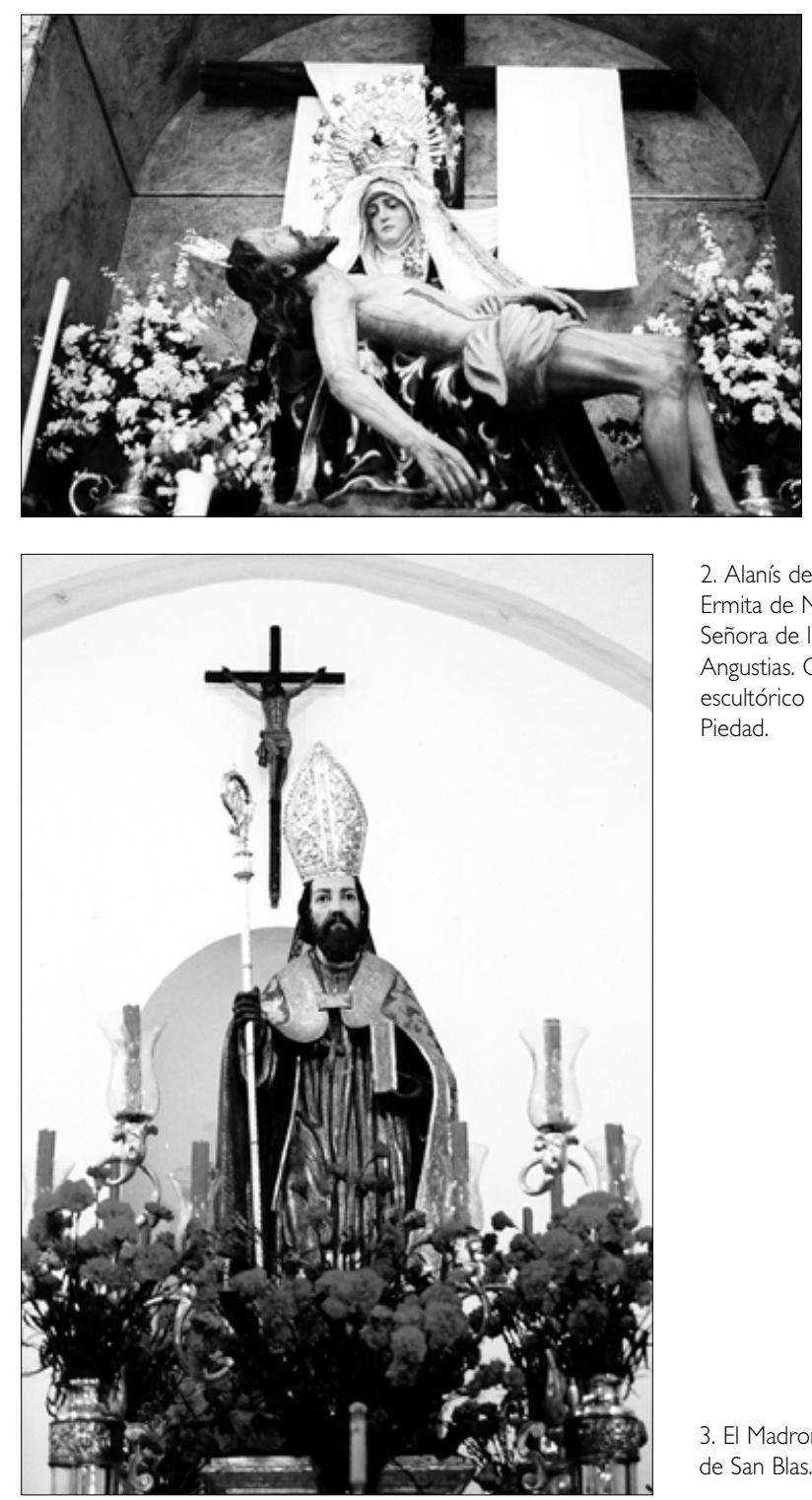

2. Alanís de la Sierra Ermita de Nuestra Señora de las Angustias. Grupo escultórico de La Piedad.

Lógicamente, esta preferencia se halla materializada en la imaginería sacra, tanto de altar como procesional, así como también en elementos de acompañamiento como insignias, emblemas, banderas y muchos otros. Incluso la iconografía de los retablos callejeros demuestra que el tema religioso más extendido es el de Nuestra Señora, desde sus orígenes en el siglo XVI hasta la actualidad ${ }^{3}$.

Pero también la afición a los santos está muy presente en Andalucía, puesto que la definitiva supremacía mariana no significa que se ignoren antiguas devociones. Por eso son mucha las poblaciones que cuentan con santos patrones, a quienes dirigen sus cultos, fiestas y romerías. Y ello sin olvidar tampoco el apego a las reliquias que se conservan en cualquier lugar de culto o que acompañan las procesiones penitenciales. Los santos siguen siendo eficaces protectores, cada uno especializado en el remedio de un determinado mal o en la consecución de un determinado bien, actuando por tanto como mediadores específicos. Bien es cierto que el avance de la técnica, al erradicar muchas plagas y epidemias y ofrecer solu-
3. El Madroño. Iglesia de San Blas. San Blas. 


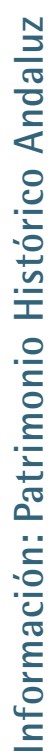
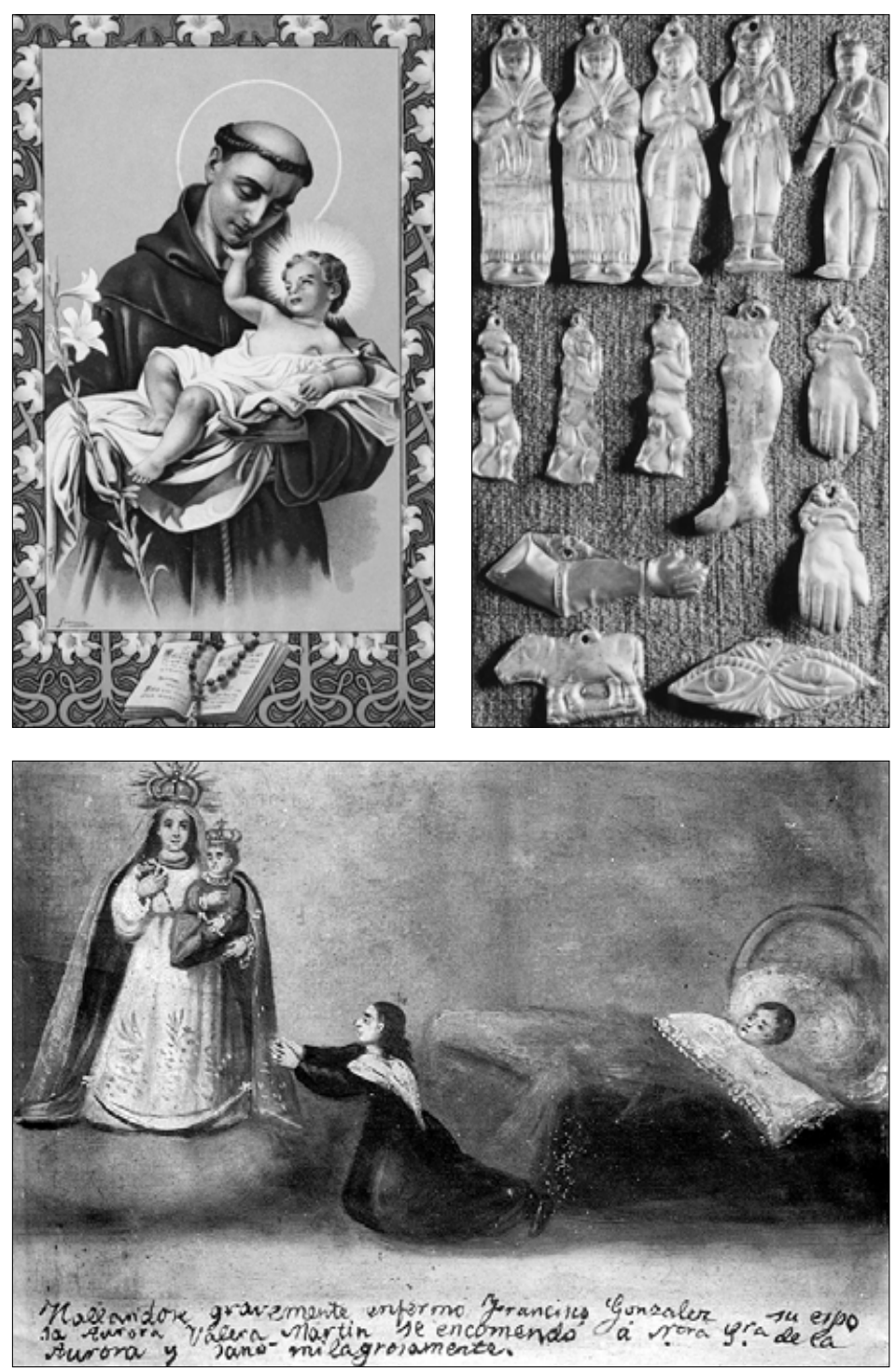

4. San Antonio con el Niño. Estampa.

5. Exvoto.

6. Los Palacios-Villafranca. Ermita de Nuestra Señora de la Aurora. Exvoto. visión utilitaria de los personajes celestiales. En el fondo, lo que se busca es la personalización de las relaciones, otra de las características más evidentes de la cultura andaluza. Ante las abstracciones y los complicados e inescrutables misterios teológicos, el pueblo necesita buscar los cauces para conseguir el acercamiento de esas figuras a un plano más humano, más cercano a su realidad, a sus pasiones y sentimientos, a los que poder solicitar su intermediación ante la lejana divinidad. Una práctica que la Iglesia ha atacado cuando la ha considerado reflejo de creencias paganas, mientras que otras veces ella misma la ha propiciado. ¿De qué otro modo puede interpretarse la inacabada costumbre de depositar exvotos a los pies de las imágenes como reconocimiento a los favores personales recibidos? ¿O cómo entender si no el sinfín de advocaciones marianas que las convierten en personalidades diferentes y hasta rivales en la devoción, cuando sólo hay una única madre de Jesús?

De hecho, la elección de una determinada advocación o de un santo concreto como patrón de una comunidad, responde al deseo de individualizar su celo protector, de no compartir su atención para que pueda ocuparse de modo exclusivo en procurar el bien de sus habitantes.

\section{Las imágenes como parte del nosotros}

Tales comportamientos se hallan reflejados, además, en la humanización que la religiosidad popular necesita volcar en la estatuaria religiosa. Lo importante son las imágenes, en las que no se ve una figura hecha en madera sino una persona concreta, individual y sin posible transposición, al igual que los individuos vivos. Ello ha conducido al aumento imparable de la explotación de sus recursos expresivos, de entre los que destaca sin duda la afición a vestir las imágenes con indumentarias espectaculares y agregarles los adornos más suntuosos de que se pueda disponer.

Las protestas eclesiales al respecto nos documentan de lo temprana de esta tendencia, como la que el padre Bernardino de Villegas publicó en 1635: "Y si bien suele ser este abuso más ordinario y común en el mundo, y trueco muy usado, en que a las imágenes las visten ya de damas, y a las damas las visten de imágenes: pero también suele aver en esta materia algún abuso en personas virtuosas; de las quales algunas, como traen el alma galana allá dentro, visten a los santos de sus oratorios con tantos dixes y galas, que es cosa indecentissima; y a vezes le da a un hombre gana de reir, viendo las bujerias que ponen a los santos; y otras de llorar, mirando la indecencia con que los santos y santas son tratados. ¿Qué cosa mas indecente, que una Imagen de nuestra Señora con saya entera, ropa, copete, valona, arandela, gargantilla, y cosas semejantes? ¿Y unas santas vírgenes vestidas tan profanamente, y con tantos dixes y galas que no traen mas las damas mas bizarras del mundo? Que, a vezes, duda un hombre, si las adorará por Santa Lucia, o Santa Catalina, o si apartará los ojos, por no ver la profanidad de sus trajes: porque en sus vestidos y 


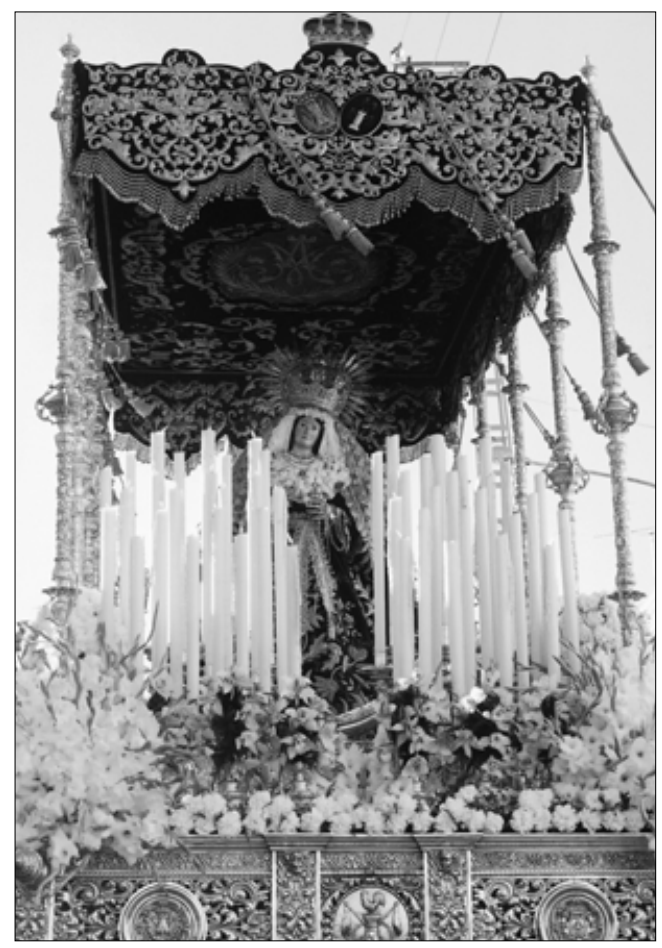

adorno no parecen santas del Cielo, sino damas del mundo: y a no estar Santa Catalina con su espada en la mano, y Santa Lucía con sus ojos en el plato, por lo que toca al vestido y traje galán con que las visten, nadie dixera que eran santas, ni vírgenes honestissimas, como lo fueron" 5 .

Desoyendo las indicaciones al respecto, la religiosidad popular andaluza siguió alimentando esta costumbre hasta el punto de que no pocas figuras de bulto fueron reconvertidas en imágenes de candelero para poder disponer la vestimenta. Así fue sucediendo con muchas pequeñas tallas góticas, especialmente vírgenes veneradas en ermitas y santuarios, para las que se confeccionaron sayas y mantos y se labraron joyas, coronas o ráfagas, a la vez que se vestía igualmente al Niño-Dios que llevan en sus manos, siguiendo las pautas de la imaginería penitencial, principal receptora de esa exuberancia ornamental. De hecho, cuando algunas de aquellas tallas se perdieron en guerras o incendios, se sustituyen con otras nuevas que, aún respetando la más de las veces la fisonomía original, son ya trabajadas directamente como imágenes de vestir.

En correspondencia con el plano más humano, la Virgen, como mujer que es, necesita un amplio y variado vestuario que luce según la ocasión, incluyendo el traje de pastora para determinados traslados por el campo y hasta el traje de luto para cuando se une al dolor por la muerte de algún destacado personaje. En los momentos de mudar la indumentaria, lo corriente es que ningún hombre pueda estar presente para no atentar contra el pudor femenino. En ocasiones existen expresas y rígidas disposiciones al respecto, como por ejemplo la referida a Nuestra Señora del Monte, patrona de Cazalla de la Sierra, dada por el cardenal Spínola a principios de siglo, en

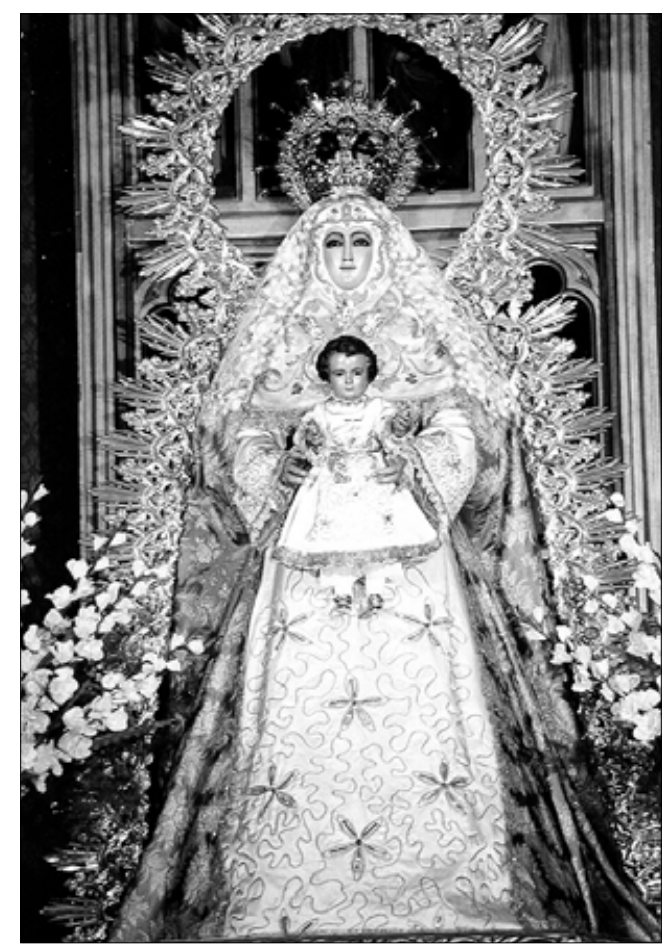

7. La Virgen del Castillo, patrona de Lebrija, en procesión.

8. Alcalá de Guadaira. Ermita de Nuestra Señoras del Águila. Nuestra Señora del Águila.

la que se prohibe que nadie pueda ver a la Virgen sin ropas a excepción de la camarera. De hecho, ésta es una de las imágenes de bulto que se comenzó a vestir en el XVIII.

Igual comportamiento puede observarse mientras se talla una nueva imagen, desde el mismo instante en que la madera va cobrando forma, desde que empiezan a configurarse unos rasgos específicos y diferenciadores. En esos momentos, y aun en el caso de tratarse de una imagen de candelero, los imagineros actúan ya como si de una persona se tratara, por lo que suelen impedir el paso a todo visitante ajeno al taller, cubriéndola, incluso, para ocultar su desnudez cuando no se está trabajando.

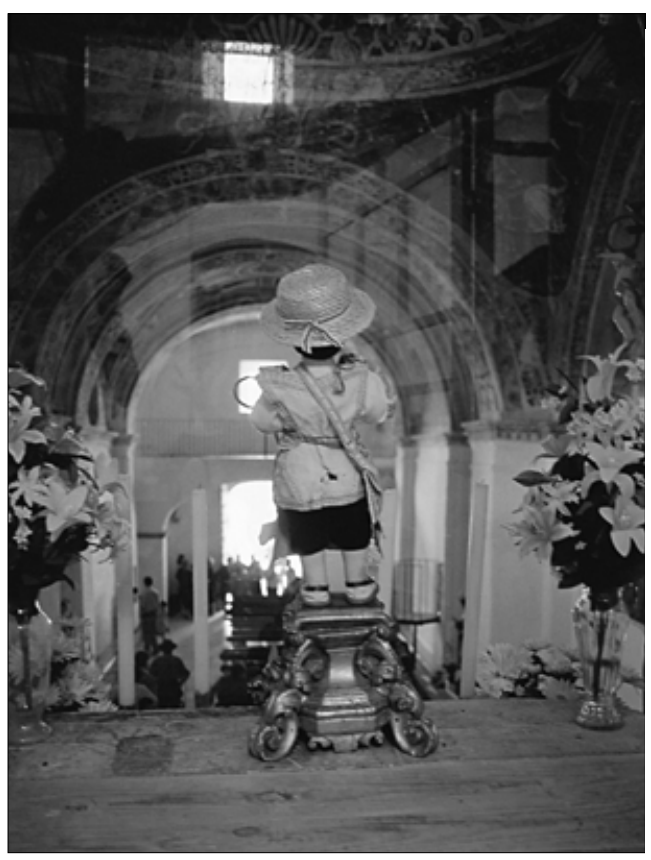

9. Guadalcanal. Ermita de la Virgen de Guaditoca. Niño bellotero

Foto: Juan Agudo 


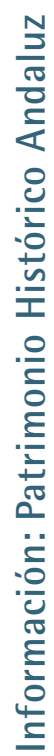
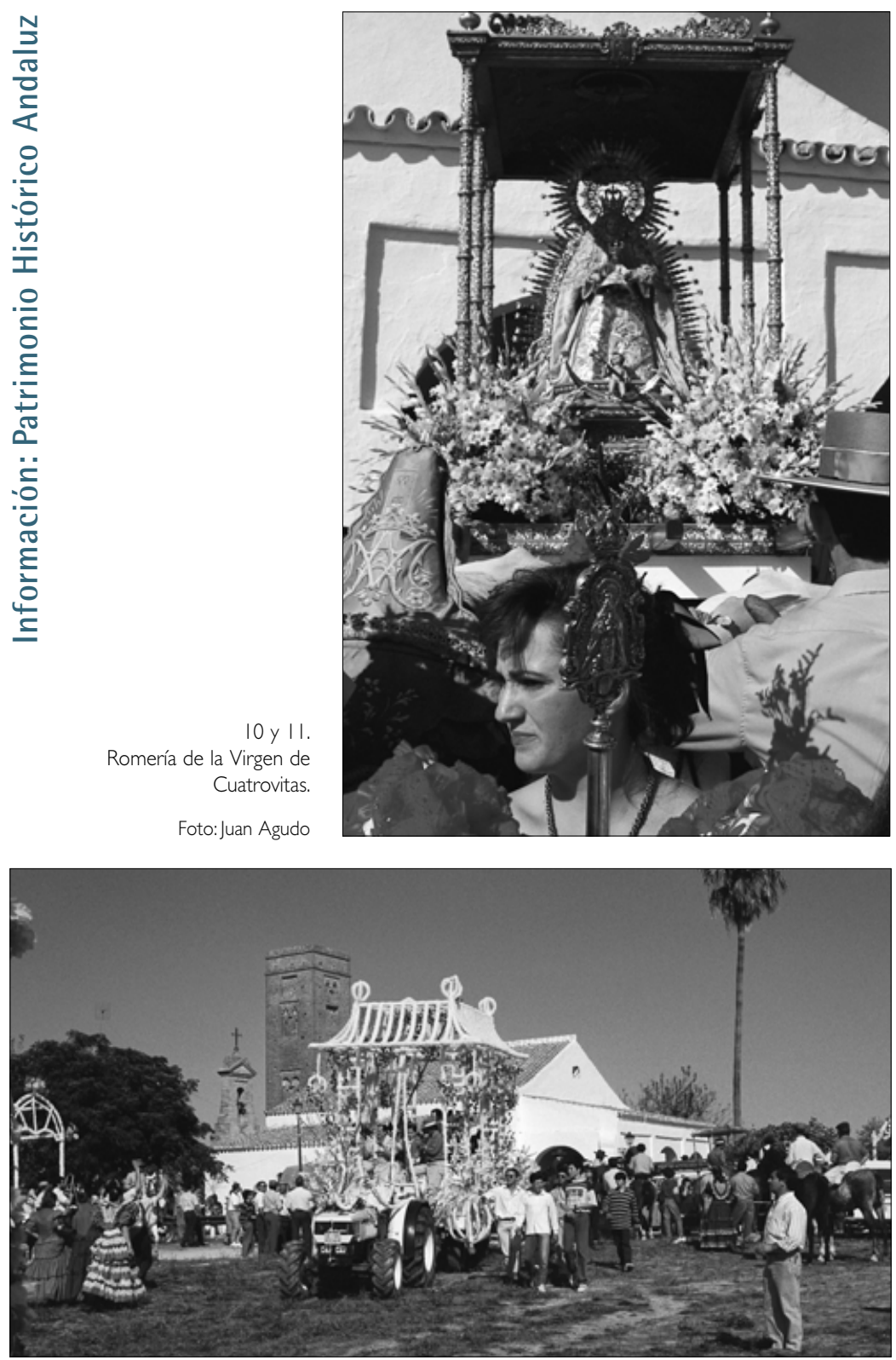

\section{El espectáculo compartido como símbolo identitario}

Teniendo todo esto presente puede entenderse fácilmente por qué el modo de sentir la religiosidad no se detiene para el andaluz en la composición de las imágenes ni en la del resto de elementos procesionales, sino que siempre se pretende el reconocimiento de que su cofradía, su Virgen, su fiesta patronal, su cruz de mayo, etc., sea la más vistosa y espectacular, compitiendo con cualquier otra devoción ajena. Competencias que sirven a su vez para renovar regular y públicamente el sentimiento de pertenencia a un determinado colectivo.

Y es que en Andalucía es innegable la importancia de los iconos religiosos como símbolos de apropiación del territorio. En tal sentido, resulta tremendamente revelador cómo en los últimos años están construyéndose ermitas en lugares en los que nunca existieron, o cofradías penitenciales en barrios de nueva construcción, con la velada finalidad de actuar como referente de

Una vez finalizada, la imagen saldrá del taller envuelta en la solemnidad que exige dicho acto, $y$, dentro de la lógica de la humanización, el siguiente paso, como en todo nacimiento, será el rito del bautismo por el que el nuevo miembro se incluye en la comunidad católica, se presenta a la sociedad y adquiere un nombre propio. Evidentemente, es la bendición eclesial de la imagen la que cumple estas funciones.

A lo largo del año, las imágenes devocionales andaluzas están presentes entre el pueblo. Se les hace partícipes de rituales como bodas, bautizos y otras muchas celebraciones como un miembro más de la comunidad. Durante las fiestas patronales, si la imagen se venera en la ermita, se la traslada a la localidad para que conviva esos días entre sus gentes. Hay ejemplos en los que se la hace participar en los actos más lúdicos de las fiestas, como la Virgen de Guaditoca en Guadalcanal, que es llevada en procesión hasta el real de la feria donde los costaleros la hacen bailar al son de marchas procesionales. Por el contrario, si la imagen se mantiene todo el unos límites espaciales.

Una característica muy extendida por la Baja Andalucía es la presencia de hermandades semicomunales, las que dividen a una comunidad en dos mitades, formalmente a efectos religiosos y ceremoniales, pero con entera incidencia en otros importantes aspectos de la organización social. Un claro ejemplo es el de la localidad aljarafeña de Carrión de los Céspedes, donde la Virgen de Consolación y la Virgen del Rosario se reparten las devociones, siendo ambas consideradas como la verdadera patrona por sus partidarios, aunque ya oficialmente sea una de ellas la elegida6; o también el de la Asunción y la Divina Pastora en Cantillana, que dividen al pueblo en asuncionistas y pastoreños, mientras que la patrona es la Virgen de la Soledad que cuenta con ermita propia. Rivalidades que se entablan igualmente con otros símbolos como las cruces de mayo, presentando idéntico esquema de división ceremo- 
nial de los habitantes de una misma localidad en cruces antagónicas, siempre con asignación territorial propia.

En el otro extremo se hallan las devociones supracomunales, ante las que cabe resaltar el hecho de estar establecidas principalmente en torno a una advocación mariana: desde el Rocío hasta la Virgen de la Cabeza. En ellas las confrontaciones se entablan entre las hermandades filiales $y$, por supuesto, entre éstas y la hermandad matriz. Recordemos cómo la Virgen de Cuatrovitas, patrona de Bollullos de la Mitación y del Gremio de la Aceituna de Verdeo del Aljarafe, tuvo hasta el siglo XVIII a Sevilla como hermandad matriz, lo que ocasionó no pocos roces con los vecinos de Bollullos.

De esta manera, las más ricas galas, las carretas mejor engalanadas, las caballerías más prestigiosas, las más reputadas bandas de música o los más afamados tamborileros, están siempre dirigidos a lograr la más lucida puesta en escena, el reconocimiento propio y ajeno de la superioridad de una concreta devoción; al tiempo que, con tales recursos expresivos, siempre se pretende el realce de cualquier manifestación de culto externo, buscando despertar las emociones tanto de sus protagonistas como del público que acude a presenciarlos, algo que se logra sin duda alguna.

En estas formas de actuación podemos ver, a su vez, la materialización de la afición de los andaluces por la teatralización de sus rituales festivo-religiosos, con una mezcla simbiótica de elementos sagrados y profanos. Por esto se viven como fiestas todas las conmemoraciones del calendario religioso, aun considerando que muchas de ellas vinieron a superponerse a festividades ya existentes, en ese empeño de la iglesia católica por erradicar o, en su defecto, cristianizar las prácticas paganas. Lógicamente, ese modo particular de expresar la ritualidad se extiende a todas aquellas festividades establecidas ex novo, sean éstas romerías, representaciones de moros y cristianos o cabalgatas de reyes magos.

Y es que la antigua mezcla de elementos sagrados y profanos se mantiene, más o menos encubierta, en todas las manifestaciones de la religiosidad popular andaluza, ignorando las reiteradas reglamentaciones eclesiásticas. Particularmente para las celebraciones de los cultos en las ermitas, los obispos del sur de España siguen insistiendo en que se acote "una zona de silencio en torno a los santuarios, evitando que llegue hasta ellos el bullicio festivo de los alrededores"7; algo que, sobre todo en determinadas devociones que mueven a miles de andaluces, parece del todo imposible de conseguir.

Igual puede decirse de otras muchas celebraciones. Aunque el pueblo andaluz siempre ha manifestado su postura frente a la injerencia eclesial, en numerosas manifestaciones de culto externo ha terminado consiguiendo que sea la Iglesia la que tenga que seguir transigiendo ante las consideradas desviaciones, por el temor de una separación definitiva entre la postura del catolicismo oficial y las expresiones de la religiosidad popular. De hecho, esta separación llega a ser casi total en algunas festividades, tales como las cruces de mayo, donde el aspecto religioso está continuamente

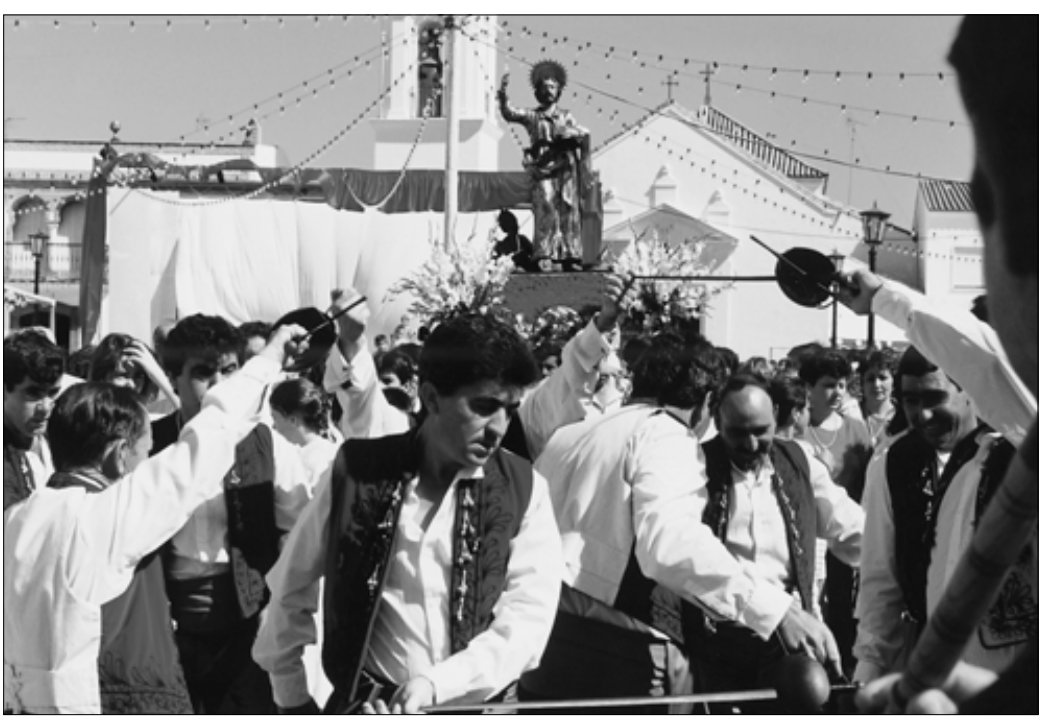

simbolizado por la santa cruz, pero en la que los representantes de la Iglesia oficial tienen ya escasa, si no nula, intervención. Ciertamente, continúa siendo la an-

12. Danza de espadas. San Bartolomé de la Torre. Huelva. Foto: Mario Fuentes cestral fiesta del pueblo en honor de la naturaleza.

Por idéntico argumento, es el propio pueblo quien asume la organización de la mayoría de sus más significativos rituales a través de hermandades, mayordomías, asociaciones, etc. Incluso la generalización de las denominadas casas de hermandad para las cofradías de penitencia, responde claramente al deseo de independencia de cada agrupación concreta respecto a las constricciones de la Iglesia.

Y son otras muchas formas tradicionales de expresar la teatralidad popular las que todavía siguen teniendo lugar, a pesar de las seculares prohibiciones eclesiásticas. Podría citarse, por ejemplo, la afición a cantar y bailar como medio de alabanza a la divinidad, que cuenta con testimonios muy antiguos. Con el tiempo, sin embargo, la Iglesia fue suprimiéndola para propiciar manifestaciones más interioristas, y aunque en los grandes núcleos de población han terminado por desaparecer con la única salvedad de los controlados seises, en las zonas rurales de mayor aislamiento estas prohibiciones jamás hallaron eco. Por ello continúan suponiendo una parte esencial de las celebraciones romeras, hoy prácticamente en su totalidad desviadas a cantes y bailes profanos, los propios del lugar, aunque también permanecen algunos reductos en Andalucía de antiguas danzas rituales, como las de lanzas o espadas y las de cascabeles y palillos, estrechamente emparentadas entre ellas. Todas son exclusivamente masculinas, tal como quedaron fijadas en la reglamentación del siglo XVIII, y suelen acompañar al patrón o patrona del pueblo, danzando sin cesar durante todo el trayecto que conduce a la ermita, donde se adentran igualmente para seguir el baile en el interior del sagrado recinto.

En este sentido, no podemos tampoco dejar de mencionar la vigencia de espectaculares montajes teatrales en el interior de las iglesias, como el que tiene lugar en Cantillana, donde el día de la Asunción se utilizan ingenios mecánicos para escenografiar dicho evento. 
Así, desde un escenario preparado al efecto, y donde en principio la imagen de la Virgen permanece oculta a la vista de los espectadores, se la va haciendo ascender hasta el centro del retablo de la iglesia, en medio de cantos, vítores y revoloteo de palomas. Una corte de niñas vestidas de ángeles acompañan a la Virgen en su subida a uno y otro lado de la rampa.

Con todo, son los recorridos romeros y los desfiles procesionales los momentos que concentran mayor afluencia de participantes y espectadores y, por consiguiente, donde cabe desplegar las mayores dosis de teatralidad. Y no sólo durante los trayectos pues, por lo general, las entradas de las imágenes en sus ermitas o templos correspondientes se alargan voluntariamente, dejando manifiesto el esfuerzo de los porteadores del paso y del que dirige la operación, siempre acompañados con música, vítores y aplausos. En ocasiones, incluso con atronadoras trabucadas, como las que suenan en honor de la Virgen de Setefilla en Lora del Río.

En cualquier caso, el mantenimiento de las singularidades de cada una de las fiestas, incluidos aspectos tales como la gastronomía propia de cada celebración, actúa como elemento de identificación que distingue el lugar de todos los demás, conformando todo un mundo cultural sentido y vivido por sus protagonistas.

\section{La materialización de unas formas de expresión cultural}

Vemos, por tanto, que las formas específicas en que se desenvuelven las manifestaciones de la religiosidad popular andaluza, se hallan tan consolidadas que resulta imposible cualquier intento de modificación. De ahí pueden llegar a comprenderse los ingentes esfuerzos del pueblo por mejorar y enriquecer continuamente sus imágenes, sus enseres procesionales y sus lugares

13. Taller de Orfebrería

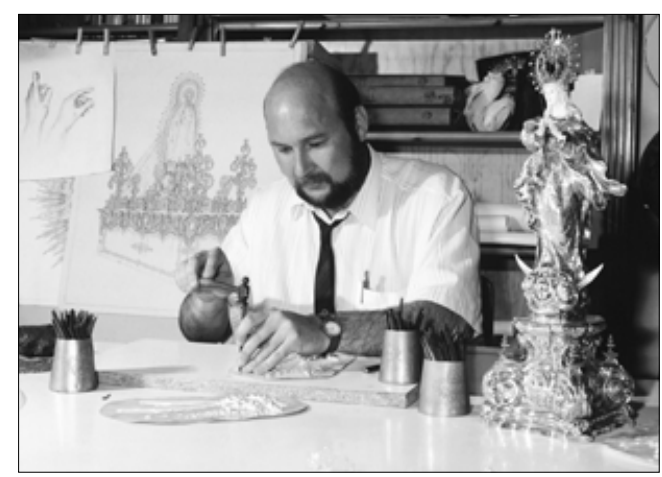

de culto, algo que sin duda coadyuva al mantenimiento de unas formas de trabajo artesanas, aun reflejando en ellas las variaciones y adaptaciones inherentes a la dinámica cultural. Y ello nos adentra en otra parte relevante de nuestro patrimonio cultural: los procesos de trabajo que dan forma a estas expresiones de nuestra religiosidad popular.

En principio, parece evidente que la proliferación y reforzamiento de las romerías en todo el territorio andaluz sustentan la pervivencia de los muchos oficios rela- cionados con el mundo del caballo, tanto guarnicionería y albardonería como talabartería que, combinando cuero y textiles, siguen surtiendo de objetos tan necesarios como zahones, arreos o sillas de montar, a los que se agregan los elementos fabricados con metales, como el bocado, los estribos o las espuelas, además de la elaboración artesana de mantas estriberas. Pero al mismo tiempo, también explica el nuevo auge que está cobrando la construcción de carruajes tirados por caballerías, imprescindibles para romerías y otras fiestas, incluyendo trabajos de ebanistería, forja y guarnicionería.

Respecto a las indumentarias específicas de los integrantes de las fiestas, son numerosos y variados los trajes asociados a un ritual determinado $y$, dentro de él, al papel asignado a quien lo porta: mayordomos, danzantes, etc., y que precisan que se mantengan vivos los conocimientos necesarios para su elaboración. Para el grueso de los asistentes, sin embargo, no cabe duda de que la influencia de romerías tan difundidas como la del Rocío, se hace sentir en cuanto a la relegación de la vestimenta propia del lugar en pro del traje campero para el hombre y el de faralaes para la mujer. A éstos últimos se vincula a su vez, en no pocas ocasiones, el mantón de Manila, una prenda singular hoy plenamente identificada con Andalucía, sin ser sus creadores, debido al uso extendido y ritualizado que le hemos prestado, junto a la consolidada adaptación de sus diseños a nuestros gustos ornamentales. Su confección industrializada alcanza ya todos los rincones, aunque todavía podemos encontrar ejecución artesana en varias localidades del Aljarafe y la Vega de Sevilla.

Tampoco cabe olvidar la música propia de estas celebraciones, tan ligada en Andalucía al tamboril y a la flauta o gaita, cuya construcción ha estado tradicionalmente ligada a la artesanía pastoril. A estos instrumentos hay que unir la omnipresente guitarra, además de palillos, panderos y otros, para los que cada vez resulta más difícil encontrar artesanos ocupados en su elaboración artesanal.

Pero, sin duda, son todos los elementos ornamentales de las imágenes los que concentran el mayor esmero y atención. La fuerza de la tradición de las peculiares características de la religiosidad popular andaluza puede explicar igualmente el hecho de que, en la actualidad, la inmensa mayoría de estos elementos continúen apegados a una peculiar estética neobarroca, como ignorando el transcurso de los siglos y los cambios sucedidos en las directrices artísticas. Sin lugar a dudas, es justamente este estilo el que mejor expresa el sentido teatral, tan arraigado en el pueblo, y el que logra mantener viva la emoción de los espectadores en sus celebraciones religiosas, a pesar de que la propia Iglesia intente hoy desvalorizar la exuberancia ornamental que ella misma propició en los momentos de feroz lucha contra la iconoclastia luterana.

Esta tendencia es perfectamente observable, como dijimos, en las vestimentas de las imágenes. Pero, es más, incluso en las tallas patronales de madera policromada que no han recibido adición de indumentaria alguna, la 
fastuosidad con que la religiosidad popular rodea siempre a sus imágenes titulares se concentra inevitablemente en las andas procesionales. En su morfología resulta cada vez más evidente la similitud con la de los pasos penitenciales, usando para ello los metales o la madera dorada o charolada, e incluyendo candelería, figuras escultóricas y exorno floral al estilo cofradiero. De hecho, para su elaboración se acude cada vez más insistentemente a los mismos talleres que trabajan de forma prioritaria para las hermandades de penitencia. $Y$ es que uno de los grupos de oficios artesanos de mayor singularidad en Andalucía es, indudablemente, el conjunto de actividades necesarias para la consecución de los elementos procesionales de la Semana Santa, compendiando en ellas unas formas de trabajo fuertemente consolidadas y altamente representativas de nuestra tradición cultural ${ }^{8}$.

Mención aparte merecen siempre los imagineros, los creadores de las obras centrales de estas manifestaciones, esto es, las imágenes titulares alrededor de las cuales gravitan los elementos decorativos. A nadie escapa la distinta consideración que se les atribuye, remontando la mera categoría artesanal para ser incluidos entre los "artistas". El mismo hecho de que los historiadores del arte vuelquen hacia ellos un gran interés (o al menos hacia su obra, que está exhaustivamente documentada y analizada), contribuye al refuerzo social de tal distinción. No obstante, aunque en otro tipo de producciones estén libres de sujeciones y puedan llegar a crear verdaderas obras innovadoras, en la actual iconografía sacra forzosamente han de mantener las pautas formales dictaminadas por el gusto popular.

En suma, son muchas las artesanías que dan vida a las expresiones de la religiosidad popular andaluza, porque muchos son los elementos precisos para su desarrollo. Todas ellas nos revelan un mundo ideológico, verdadero patrimonio cultural de los andaluces, que ha determinado incluso el desenvolvimiento de la propia actividad, porque la vida de los talleres (su organización interna, las relaciones con los clientes, la jerarquización del trabajo, los grados de especialización, el sistema de aprendizaje, la elección de materias primas, instrumentos y técnicas, y hasta su propia esperanza de continuidad), está fuertemente influida por las ideas de la religiosidad popular andaluza y por las fórmulas estéticas que sirven a la expresión de esas ideas.

La situación presente de cada uno de estos oficios refleja a su vez el continuo esfuerzo adaptativo de nues- tras tradiciones culturales, que origina la pérdida, pervivencia o introducción de determinados materiales o técnicas de elaboración y que, consiguientemente, reclama la debida atención por parte de las instancias encargadas de velar por su documentación.

\section{La valoración de un patrimonio propio}

En resumen, del análisis antropológico de la ritualidad andaluza se desprenden datos de incuestionable valor para la comprensión de nuestra ideología y nuestra estructura social, reproducida simbólicamente en cada una de nuestras celebraciones ${ }^{9}$. Claramente la religiosidad popular entraña formas de expresión cultural que rebasan con mucho el aspecto puramente religioso y que, como tales, deben ser objeto de la adecuada atención patrimonial en sus múltiples vertientes: lugares, bienes, saberes y conductas fruto de la tradición cultural, tal como contempla expresamente en su Título VII la Ley de Patrimonio Histórico Andaluz.

Atendiendo a estos enunciados, parece que al fin se ha superado la añeja consideración esteticista de los tesoros histórico-artísticos para dar paso a una visión más antropológica, para la cual son los valores inmateriales que se le atribuyen a los objetos de referencia (sea cual sea el soporte en que se encuentren) los que definen su significación cultural y los que justifican las razones argumentables para su preservación 10 . De esta forma, cuando hablamos específicamente de los bienes culturales emanados de nuestra religiosidad popular, no cabe ya, por tanto, limitar la selección de los mismos a unas determinadas realizaciones materiales supuestamente valorables en sí mismas: por su firma, su estilo, sus trazos, su genialidad en definitiva. Muy al contrario, su valor principal siempre será el de constituir el testimonio de una identidad cultural, de un modo de expresión colectivo, vivo, dinámico y cambiante.

De ahí el interés de una ermita, una talla anónima o una carreta rociera. De ahí el respeto que debe presidir la elección de los criterios a aplicar en toda restauración. De ahí la importancia de documentar unas específicas técnicas de trabajo o unas concretas formas de relación. De ahí la inevitabilidad de insertar estos bienes en su contexto sociocultural. De ahí, sobre todo, la congruencia de que sea el propio pueblo andaluz quien, también en este caso, tenga la potestad de decidir sobre un patrimonio que le pertenece.

\section{Notas}

I. Carlos Domínguez Morano: "Aproximación psicoanalítica a la religiosidad tradicional andaluza" en La religión en Andalucía. Sevilla, 1985, pp. | 36-142

2. Antonio Limón Delgado: Andalucía ¿tradición o cambio?. Sevilla, 1988, pp. 163-164

3. Eva Fernández de Paz: Religiosidad popular sevillana a través de los retablos de culto callejeros. Sevilla, 1987, pp. 72-78.

4. Antonio Limón Delgado: Costumbres populares andaluzas de nacimiento, matrimonio y muerte. Sevilla, 198I, pp. 100 y 45.

5. La esposa de Christo, instruida con la vida de Santa Lutgarda, v. V, c. XVIII, pp. 430-43I. Cifr. Julio Caro Baroja: Las formas complejas de la vida religiosa. Madrid, 1978, p. II6.
6. Isidoro Moreno Navarro: Propiedad, clases sociales y hermandades en la Baja Andalucía. Madrid, 1972.

7. Las Hermandades y las Cofradías. Carta pastoral de los Obispos del Sur de España, n 51. Madrid, 1988, p. 62.

8. Esther Fernández de Paz: Los Artífices Sevillanos de la Semana Santa Andaluza. El Ornato Tradicional. Sevilla, 1998.

9. Juan Agudo Torrico: "Romerías, ferias y fiestas. Significados y funciones de las fiestas andaluzas" en Conocer Andalucía, v. VI. Sevilla, 2000, pp. 256-303.

10. Esther Fernández de Paz y Juan Agudo Torrico (coords.): Patrimonio Cultural y Museología. Significados y Contenidos. Santiago de Compostela, 1999, pp. 7- 15. 